\title{
COVID-19, PSYCHOSOCIAL EFFECTS AND FAKE NEWS
}

\author{
Reneta NIKOLOVA, Alexander YANKOV \\ "Neofit Rilski" South-West University, Blagoevgrad, Bulgaria \\ renyfia@abv.bg, alexander.yankov1990@gmail.com
}

\begin{abstract}
: 2020 will be defined as crucial for the human race, as well as the year that marked the new era in human history and international development. In times of epidemic or pandemic, people tend to be afraid of being infected with the virus, resulting in feelings of stress, fear and depression Global health problems connected with COVID-19 have also highlighted the importance of combating disinformation that can cause high level of panic and social unrest. Fake news and COVID-19 have been going hand-in-hand since the very beginning. The WHO director-general has referred to it as "coronavirus infodemic" which is breeding fright and panic by laying out unchecked rumors or 'sensational' news.
\end{abstract}

\section{Keywords: COVID-19, psychosocial}

\section{Introduction}

2020 will be defined as crucial for the human race as well as the year that marked the new era in human history and international development. Global health problems connected with COVID-19 have also highlighted the importance of combating disinformation that can cause high level of panic and social unrest. All media has been attacking daily with news about the number of cases, deaths, methods of self-protection and means of prevention and treatment of the disease. It has been reported that the necessary isolation at home, the avoidance of social contacts, and the excessive exposure to information about COVID-19 in the media and social media adversely affects psychological well-being of some people and vulnerable groups.

Centuries after the cholera and plague outbreaks across Europe, the world has proved not prepared for COVID-19. There are many points where COVID-19 has differed from other pandemics, and which effects, fake news, disinformation

have resulted in increased negative effects in many areas of social life.

Compared to the early 21 st century SARS, MERS, Zika and Ebola outbreaks, coronavirus differs in its scale and scope. While measures applied during almost all previous pandemics were mostly limited to rules for personal hygiene and sanitation, with regard to COVID-19 not only local and regional measures, but also national lockdowns, social distancing rules and strict travel restrictions were applied almost all over the world. Although the measures varied significantly both regionally and at the country level there nevertheless has been a common global response coordinated by World Health Organizatition (WHO).

\section{Digital age and combating disinformation and fake news \\ The digital age arrives with a set of major communication challenges for traditional mainstream media: new audience}


relationships (interactivity), new languages (multimedia) and even a new grammar (hypertext). The news manages to reach much larger groups of people in a much shorter time, which makes individuals much more aware of what is happening around them and anywhere in the world.

Fake news could constitute the deliberate dissemination of false (often defamatory) information, but also fake news exists, and when an allegation rests on a minimal dose of truth. What can be argued with certainty, however, is the direct link between the false news and the conduct of misinformation. One of the main problems with fake news is that they spread on the internet much faster than the real ones. The purpose of fake news is to mislead the audience they reach (and this happens most quickly online), with the 'authors' of such news receiving financial or political benefits from it.

In response to fake news, many media sources started to unite forces in order to counter it. They all are trying to learn their viewers and readers to recognize false information and to help them to avoid becoming victims of fake news. So, reputable media around the world create classifications of types of fake news in order to make it easier to recognize them, as well as publish articles with tips on how to make an adequate check in case of suspected fake news.

Disinformation is the deliberate dissemination of misinformation or inaccurate information for propaganda purposes. In addition, disinformation involves distorting true information in such a way as to make it useless. In principle, disinformation is defined by researchers as "the dissemination of deliberately false information especially when supplied by a government or its agent to a foreign power or to the media with the intention of influencing the policies or opinions of those who receive it; false information so supplied" [3].

In 2014, the World Economic Forum in Davos highlighted the rapid spread of disinformation online as one of the top ten trends in modern societies.

Large-scale disinformation of citizens, including through misleading or frankly false information, presents a huge challenge for Europe too.

Disinformation undermines trust in institutions, as well as in digital and traditional media, and is a blow to democracy as it prevents citizens from making evidence-based decisions. It often feeds radical and extremist ideas and actions. Disinformation also interferes with a freedom of expression, a fundamental right enshrined in the Charter of Fundamental Rights of the European Union [1].

In April 2018, the European Commission presented a European approach and selfregulatory tools to combat online disinformation, including an EU-wide code of conduct on disinformation, support for an independent network of fact-checkers and tools to stimulate quality journalism.

On 16 October 2018, the Code of Practice on Disinformation was signed by Facebook, Google, Twitter and Mozilla, as well as by trade associations representing online platforms and the advertising industry. Microsoft joined the Code in 2019. The signatories submitted self-assessments in October 2019.

EU Commissioner for Digital Economy and Society at that time Mariya Gabriel welcomed this step, but also urged platforms to step up their efforts to combat the spread of disinformation online [6].

"The Code of Practice submitted today by the industry is the first tangible outcome of the Communication that the Commission adopted last April.

It is an important step in tackling a problem which has become increasingly pervasive and threatens Europeans' trust in democratic processes and institutions. This is the first time that the industry has agreed on a set of self-regulatory standards to fight disinformation worldwide, on a voluntary basis. The industry is committing to a wide range of actions, from transparency in 
political advertising to the closure of fake accounts and demonetisation of purveyors of disinformation, and we welcome this. These actions should contribute to a fast and measurable reduction of online disinformation. To this end, the Commission will pay particular attention to its effective implementation".

In 2019 on forum in Bratislava Mariya Gabriel also stressed the need to expand knowledge of the mechanisms by which disinformation is created and disseminated. To this end, the European Commission supports quality journalism because the human factor is crucial in adapting the democratic model for the digital age. The Bulgarian Commissioner for Digital Economy and Society pointed out that media pluralism and freedom, development of citizens' digital skills to listen and read are extremely important for the preservation of democracy [11].

\section{COVID-19 and disinformation}

Since the end of 2019 the world has been changed due to a virus of the corona family that caused thousands of deaths. Its official name was "severe acute respiratory syndrome coronavirus 2 (SARS-CoV-2)," but popularly known as 'coronavirus' or 'COVID-19'.

It was first identified in December 2019 in China. The World Health Organization declared the outbreak a 'public health emergency of international concern' (PHEIC) on January 30th, 2020, and recognized its pandemic status on March $11^{\text {th }}$ of the same year.

"This is not just a public health crisis, it is a crisis that will touch every sector," said Dr.

Tedros Adhanom Ghebreyesus, WHO director-general, at a media briefing [8].

The challenge imposed by coronavirus still continues, since even the countries with the best hospital structures cannot fully support a high percentage of their population $[9,10]$. In times of epidemic or pandemic, people tend to be afraid of being infected with the virus/disease, resulting in feelings of stress, fear and depression. Stress can be defined as a feeling of emotional and physical tension that results from any event that threatens a person's homeostasis. On the other hand, the fear of the unknown is called anxiety, i.e., the body's natural response to stress. Depression is a condition in which a person is indifferent to daily activities. It is argued that people experiencing a pandemic without vaccination will be called upon by the fear of the unknown which in turn leads to anxiety and depression [5]. According to neuropsychology, fear is a normal reaction to an evolving threat, preparing the individual to react physically and mentally to a potential injury. These extreme psychosocial effects have been reinforced by misinformation related to COVID-19 and spread on social media. The above situation leads that the WHO directorgeneral has referred to it as "coronavirus infodemic" which is breeding fright and panic by laying out unchecked rumors or 'sensational' news [7].

Fake news and COVID-19 have being going hand-in-hand since the very beginning. Misinformation and the cover up of the situation by official authorities raise even more suspicion around the 'double death' of Chinese Dr. Li who tried to warn others about the corona virus outbreak. One of the latest examples is connected with the online disinformation that has recently led to a sluggish vaccine roll-out in Ivory Coast. In some parts of Africa vaccination is accompanied by lots of rumours and fake news.

Some national authorities like the Greek Ministry of Health has published some interesting suggestions about the possible ways to preserve mental health during the coronavirus pandemic [4]. The most important one seems to be connected with the correct information about the virus from credible sources and limiting media exposure, as repeated and incessant exposure to the media increases stress and discomfort levels. It can also be a source of 
misinformation. At the same time, although overuse of technology can be harmful, it is worth noting that the same technologies improve people's quality of life. During the lockdown period, new technologies and the internet were widely used for healthier lifestyle and fitness (40\%), for communicating with doctors $(41 \%)$, and for improving mental health and well-being $(43 \%) . \%)$ [4].

\section{Conclusion}

In view of the aforementioned, it could be inferred that the pandemic has been accompanied by a massive wave of false or misleading information, including in the framework of the European Union. Apart from physical sufferings, the consequences of the pandemic and the 'infodemic' on the mental health and well-being at personal and population-levels are harmful. The European leaders are proposing some necessary steps to combat disinformation around the COVID-19. The High Commissioner Josep Borrell pointed out that: "Disinformation in times of the coronavirus can kill. We have a duty to protect our citizens by making them aware of false information, and expose the actors responsible for engaging in such practices. In today's technology-driven world, where warriors wield keyboards rather than swords and targeted influence operations and disinformation campaigns are a recognised weapon of state and non-state actors, the European Union is increasing its activities and capacities in this fight" [2].

\section{References List}

[1] Charter of Fundamental Rights of the European Union, Official Journal, 2012/C 326/02, Art.11.

[2] Coronavirus: EU strengthens action to tackle disinformation (europa.eu)

[3] McGonagle, Tarlach, Bednarski, Maciek, Coutinho Mariana Francese \& Arthur Zimin. Elections and Media in Digital times. Elections and Media in Digital Times $\mid$ The Communication Initiative Network (comminit.com)

[4] Mpravou, A., Madourou, K., Vasileiou, G. \&Gonidakis, F. (2020). Mental management of the COCID-19 pandemic in the general population. Athens: Ministry of Health and National and Kapodistrian University of Athens. (In the Greek language).

[5] Rehman, U., Shahnawaz, M. G., Khan, N. H., Kharshiing, K. D., Khursheed, M., Gupta, K., ... \&Uniyal, R. (2020). Depression, anxiety, and stress among Indians in times of Covid-19 lockdown. Community Mental Health Journal, 1-7. DOI: 10.1007/s10597020-00664-X.

[6] Statement by Commissioner Gabriel on the Code of Practice on Online Disinformation Brussels, 26 September 2018. Statement by Commissioner Gabriel on the Code of Practice on Online Disinformation (europa.eu)

[7] Souvik Dubey, Payel Biswas, Ritwik Ghosh, Subhankar Chatterjee, Mahua Jana Dubey, Subham Chatterjee, Durjoy Lahiri, Carl J. Lavie Psychosocial impact of COVID-19. I Diabetes \& Metabolic Syndrome: Clinical Research \& Reviews 14 (2020) 779-788.

[8] The WHO Just Declared Coronavirus COVID-19 a Pandemic | Time

[9] Белова Г., Н. Марин, Й. Кочев COVID-19 и киберпрестьпленията срещу здравеопазването, сп. „Национална сигурност”, ISSN: 2682-941X \& ISSN: 26829983, https://nacionalna-sigurnost.bg/sdm_downloads/cyber-crimes/

[10] Иванов Г. Националната сигурност на държавата в условията на пандемия от коронавирус, сп. „Национална сигурност”, бр. 3, ISSN: 2682-941X \& ISSN: 2682$9983 \mathrm{https}: / /$ nacionalna-sigurnost.bg/broi-3/

[11] Мария Габриел: Ролята на европейските регулатори е ключова в борбата с дезинформацията | XNEWS 